\title{
What regulates crab predation on mangrove propagules?
}

\author{
Fleur Van Nedervelde ${ }^{\text {a, c, * }}$, Stefano Cannicci ${ }^{b}$, Nico Koedam ${ }^{\text {c }}$, Jared Bosire ${ }^{\mathrm{d}}$, \\ Farid Dahdouh-Guebas ${ }^{\text {a, }} \mathrm{c}$ \\ ${ }^{a}$ Laboratory of Systems Ecology and Resource Management, Université Libre de Bruxelles-ULB, Campus de la Plaine, Av. F.D. Roosevelt 50, CPI 264/1, B-1050 \\ Brussels, Belgium \\ ${ }^{\mathrm{b}}$ Department of Biology, Università degli Studi di Firenze, Via Madonna del Piano 6, I-50019 Sesto Fiorentino, Italy \\ c Laboratory of Plant Biology and Nature Management, Vrije Universiteit Brussel-VUB, Pleinlaan, 2, B-1050 Brussels, Belgium \\ ${ }^{\mathrm{d}}$ Kenya Marine and Fisheries Research Institute, PO Box 81651, Mombasa, Kenya
}

\section{A R T I C L E I N F O}

\section{Article history:}

Received 30 August 2013

Received in revised form

28 November 2014

Accepted 28 November 2014

Available online 5 December 2014

\section{Keywords:}

Decapod

Competition

Predation

Propagule

Gazi Bay

\begin{abstract}
A B S T R A C T
Crabs play a major role in some ecosystems. To increase our knowledge about the factors that influence crab predation on propagules in mangrove forests, we performed experiments in Gazi Bay, Kenya in July 2009. We tested whether: (1) crab density influences propagule predation rate; (2) crab size influences food competition and predation rate; (3) crabs depredate at different rates according to propagule and canopy cover species; (4) vegetation density is correlated with crab density; (5) food preferences of herbivorous crabs are determined by size, shape and nutritional value. We found that (1) propagule predation rate was positively correlated to crab density. (2) Crab competitive abilities were unrelated to their size. (3) Avicennia marina propagules were consumed more quickly than Ceriops tagal except under C. tagal canopies. (4) Crab density was negatively correlated with the density of A. marina trees and pneumatophores. (5) Crabs prefer small items with a lower C:N ratio.

Vegetation density influences crab density, and crab density affects propagule availability and hence vegetation recruitment rate. Consequently, the mutual relationships between vegetation and crab populations could be important for forest restoration success and management.
\end{abstract}

(c) 2014 Elsevier Masson SAS. All rights reserved.

\section{Introduction}

The mangrove ecosystem is unique; as a forested vegetation it is remarkably well adapted to high salt concentrations, hypoxic to anoxic soils, and is influenced by tidal action in most of its ecological settings (Krauss et al., 2008). The mangrove ecosystem structure is affected by various abiotic (e.g. temperature, salinity, nutrient, tidal amplitude, topography) and biotic factors (e.g. interand intra-specific competition, interactions with fauna, anthropogenic pressure) (Lee, 1999).

Impacts of mangrove fauna are predominantly due to crab activity, as they are the most abundant macrofauna taxon in mangroves (Macnae, 1968; Cannicci et al., 2009). Some authors refer to crabs as keystone species in mangrove ecosystem (Macnae, 1968; Schories et al., 2003; Kristensen, 2007; Amarasinghe et al., 2009;

\footnotetext{
* Corresponding author. Laboratory of Systems Ecology and Resource Management, Université Libre de Bruxelles-ULB, Campus de la Plaine, Av. F.D. Roosevelt 50 CPI 264/1, B-1050 Brussels, Belgium.

E-mail address: fleur@vannedervelde.be (F. Van Nedervelde).
}

Cannicci et al., 2009; Lindquist et al., 2009). Crabs can affect forest structure through at least two activities: burrowing (Macnae, 1968; Cannicci et al., 2009) and herbivory (Schories et al., 2003).

Some herbivorous crab families are known to depredate on propagules. This predation can affect mangrove regeneration in natural and restored stands (Dahdouh-Guebas et al., 1998), and they can also regulate competitive interactions between tree species in high density reforested stands (Bosire et al., 2005). Most decapods are opportunistic feeders and exploit a wide range of food sources (Cannicci et al., 2007). Sesarmid crabs are predominantly herbivorous (Dahdouh-Guebas et al., 1999), but do not exclusively feed on leaf litter (Bouillon et al., 2002a,b; Thongtham and Kristensen, 2005). While some arboreal climbing species actively forage on tree leaves (Cannicci et al., 1996), the majority of herbivorous sesarmid crabs rely on mangrove litter made up of leaves and seasonal propagules (Nicholson, 2009). Arboreal herbivorous climbing species can affect propagules before dispersal by increasing premature propagule abscission rate (Farnsworth and Ellison, 1997). Other decapods may damage propagules after abscission (Smith, 1987; Wilson, 1989; Robertson et al., 1990). 
Most mangrove species are viviparous and produce fruit, propagules or seeds that can disperse through water (Macnae, 1968; Tomlinson, 1986; Tomlinson and Cox, 2000). However, these adaptations do not prevent predation and crabs may access to propagules of species other than the locally dominant ones (Dahdouh-Guebas et al., 1998; Bosire et al., 2005).

Crab predation on propagules could be affected by many factors such as predation pressure on crabs, inter- and intra-specific competition, reproductive period, and season (Erickson et al., 2004). The most influential factors of predation rate are the amount (Beever et al., 1979) and size (Emmerson and McGwynne, 1992; Nordhaus et al., 2006) of predators, food availability (Smith, 1987) and vegetation cover (Osborne and Smith, 1990; Farnsworth and Ellison, 1991; Clarke and Kerrigan, 2002). The nutritional value (Smith, 1987; Farnsworth and Ellison, 1991; McKee, 1995; Clarke and Kerrigan, 2002; Ditzel Faraco and da Cunha Lana, 2004; Nordhaus et al., 2011), nature (leaf or propagule) (Salgado Kent and McGuinness, 2008), size (Salgado Kent and McGuinness, 2008; Camilleri, 1989) and shape of the food can also lead to different feeding preferences and rates.

This study focuses on the predation behaviour of two herbivorous crab species: Neosarmatium africanum Ragionieri, Fratini and Schubart (formerly Neosarmatium meinerti De Man) and Neosarmatium smithii $\mathrm{H}$. Milne Edwards. We examined their feeding habits and the factors that could influence their predation behaviour. Specific objectives of the study were to evaluate: (1) whether predation rate increases with crab density ( $c f$. Dahdouh-Guebas et al., 1998); (2) whether larger crabs are dominant food competitors and thus depredate more propagules; (3) whether propagules from two species are depredated at the same rate and if the rate of crab predation on propagules are affected by the propagule species, dominant canopy trees, and crab species; (4) whether higher tree densities lead to higher crab densities and a higher predation rate on propagules; (5) whether species, size, nature (leaf or propagule), colour or C:N ratio of the food items influence crab preferences.

\section{Materials and methods}

\subsection{Study area and organisms}

Fieldwork was conducted in the mangrove forest of Gazi Bay on the southern coast of Kenya, situated $50 \mathrm{~km}$ south of Mombasa ( $4^{\circ}$ $25^{\prime} \mathrm{S}$ and $39^{\circ} 30^{\prime} \mathrm{E}$ ). This mangrove forest is dominated by Avicennia marina (Forssk.) Vierh., Rhizophora mucronata Lamk. and Ceriops tagal (Perr.) C.B.Robinson and has a total area of $6 \mathrm{~km}^{2}$ (Neukeurmans et al., 2008). Data was collected from the end of June

\section{Table 1}

Forest structure, crab zonation, soil characteristics and inundation level. Adapted from Matthijs et al. (1999) and Dahdouh-Guebas et al. (2002).

\begin{tabular}{|c|c|c|c|c|}
\hline & $\leftarrow$ Land & & Creek $\rightarrow$ & References \\
\hline $\begin{array}{l}\text { Dominant cover } \\
\text { species }\end{array}$ & C. tagal & A. marina & R. mucronata & \\
\hline $\begin{array}{l}\text { Dominant crab } \\
\text { species }\end{array}$ & N. africanum & N. africanum & N. smithii & \\
\hline \multicolumn{5}{|l|}{ Soil variables } \\
\hline Eh $(\mathrm{mV})$ & -204 & -182 & -288 & $\begin{array}{l}\text { Matthijs et al. } \\
\text { (1999) }\end{array}$ \\
\hline $\mathrm{NaCl}(\mathrm{g} / 100 \mathrm{~g})$ & 4.4 & 5.3 & 3.4 & \\
\hline $\mathrm{pH}$ & 6.44 & 6.41 & 6.84 & \\
\hline Substate & Sandy & Sandy & $\begin{array}{l}\text { Dark grey } \\
\text { muddy }\end{array}$ & \\
\hline \multicolumn{5}{|l|}{ Hydrology } \\
\hline $\begin{array}{l}\text { 'Height above } \\
\text { datum'-range } \\
\text { (m) }\end{array}$ & $2.10-2.60$ & $2.60-3.10$ & $1.50-2.00$ & $\begin{array}{l}\text { Dahdouh-Guebas } \\
\text { et al. (2002) }\end{array}$ \\
\hline
\end{tabular}

to the beginning of August 2009, during the drier period of the rainy season. We have chosen that period because it is characterized by a high abundance of mature propagules of $A$. marina and C. tagal. We observed crabs at low tide when they were out of their burrows and more active. According to Micheli et al. (1991), crab activity depends mainly on the light-dark cycle. Their activity declines dramatically during the night. They are more active around sunset and sunrise or during the day, but in the latter case they stay in protected, shaded biotopes to avoid the risks of predation by birds (Micheli et al., 1991) and desiccation (Fusi et al., unpublished results). The study site was an area of $1 \mathrm{~km}^{2}$ with a $R$. mucronata stand at lower tidal elevations, a $C$. tagal stand at the higher tidal elevations and a A. marina stand located in between them (Table 1). We have chosen this site since it is inhabited by the two largest herbivorous sesarmids: $N$. smithii and $N$. africanum. These species are distributed in association to vegetation species, inundation level, and soil characteristics (Table 1). N. africanum is found in the zone with $A$. marina and $C$. tagal cover, and $N$. smithii is found in the adjacent zone with $R$. mucronata cover (Table 1 ). Both crab species are assumed to usually encounter propagules of $A$. marina and C. tagal. We tested crabs of which the burrows were less than five metres away from A. marina or C. tagal trees. Propagules can fall on the ground and self-planted in soil or can fall in water and be transported by current (Dahdouh-Guebas et al., 1998; Bosire et al., 2005) becoming easily accessible to crabs from another area at low tide (personal observation). The randomization in our experiments was usually made by arbitrary selection of coordinates with a GPS or with the aid of a hand-drawn map where trees, roots, and burrows were represented. In some cases, we threw a stone and used the drop place as the left-hand bottom corner of our plot. We distributed our replicas through space but also through time in order to avoid crabs to become used to the experiment. Nonetheless, some replicas of some experiments were carried out simultaneously, to save time.

\subsection{Impact of crab density on predation}

In order to observe how predation varies with crab density, we placed five A. marina or C. tagal propagules in a $2 \mathrm{~m}^{2}$ plot. The 17 or 20 different crab density zones were chosen one by one after $20 \mathrm{~min}$ of observation. The experiment was repeated in 20 randomly chosen plots for each density ranges of $1-3 \mathrm{crabs} / \mathrm{m}^{2}$, 4-6 crabs $/ \mathrm{m}^{2}$ and $7-15 \mathrm{crabs} / \mathrm{m}^{2}$. This was carried out over approximately 14 days, distributed over a 6 week period. We noted how many propagules were depredated under $A$. marina stand 10 min after the propagules were placed in position, and under $R$. mucronata stand after $15 \mathrm{~min}$. We established these exposure times based on the mean time for crabs to depredate the mean quantity of propagules under a mean crab density. The observer was at least ten metres away from the plots and was assumed to be out of sight of the crabs. We assumed that propagules had been depredated when they were inside a crab burrow.

\subsection{Importance of crab size in food competition}

To investigate intra-specific competition for food amongst $N$. africanum, and to establish the variation of the predation rate between different crab sizes, we randomly chose and observed pairs of crabs in an A. marina zone. We retained pairs which exited their burrows in front of each other, and which were moving in the same direction, in order to avoid displaying favouritism towards one individual from a studied pair. The minimum carapace width difference between the individuals of each pair was at least $1.5 \mathrm{~cm}$. Before the experiment, we determined an approximate size of each crab, and after the experiment we caught the crabs and took 
measurements. If pairs did not show the appropriate range of size difference we deleted the corresponding data. We placed a propagule of $A$. marina at an equal distance from two crabs of different sizes. We then observed and noted which crab (either the largest or the smallest) carried the propagule inside its burrow first. The observer was at least five metres away from the burrows. We excluded results when a crab not from the chosen pair took the propagule first or when, only one member of the pair reacted. We repeated the experiment 15-18 times for each pair, and we tested a total of 11 pairs of crabs. This took us approximately 5 days distributed throughout a 6 week period.

\subsection{Rates of crab predation on propagules}

To test whether different propagule species are depredated at the same rate, and whether canopy covers and crab species affect this rate, we compared the quantity of depredated propagules exposed to herbivorous crab populations as a function of time for both propagule species, and under three different covers. We placed 200 propagules of $C$. tagal or A. marina inside $2 \mathrm{~m}^{2}$ plots under A. marina, $C$. tagal and $R$. mucronata canopies. The plots were marked out in such a way to facilitate observation but also to allow outsider crabs to enter the plot and depredate on propagules. We repeated this experiment 15-20 times under each tree species cover. Each plot was randomly chosen and crab density was measured over a 20 min observation period. We checked how many propagules had been depredated on, and how many had been left undamaged in the plot every $15 \mathrm{~min}$ for $2.15 \mathrm{~h}$, or until there were no more non-depredated propagules left. The observer was out of sight, at least ten metres away from the plots and behind dense vegetation during the whole $15 \mathrm{~min}$ period. We also assumed that propagules had been depredated when they were inside a crab burrow. This took us approximately 12 days distributed throughout a 6 week period.

\subsection{Relationship between vegetation density and crab density}

To test whether crab density was linked to vegetation density, we randomly selected 20 plots of $2 \mathrm{~m}^{2}$ inside five different A. marina density areas: $0 \mathrm{~m}^{-2} ; 0.5 \mathrm{~m}^{-2} \pm 0.2 ; 1.5 \mathrm{~m}^{-2} \pm 0.3$; $3.5 \mathrm{~m}^{-2} \pm 0.2$ and isolated trees. We determined the tree densities by counting the trees inside five randomly chosen $25 \mathrm{~m}^{2}$ quadrats in an A. marina zone. Since the quantity of $A$. marina pneumatophores is affected by oxygen availability, topography, and tide level (Dahdouh-Guebas et al., 2004, 2007), we avoided differences in topography and soil conditions by choosing five adjacent plots. We assumed that the majority of environmental factors were similar or that they had negligible differences because of their adjacent positions. We measured $N$. africanum density in each plot, during 20 min of observation, and pneumatophore density. This took us approximately 5 days distributed throughout a 6 week period.

\subsection{Food preference}

Although the most usual method for studying what an organism eats is gut content analysis (Dahdouh-Guebas et al., 1999; Erickson et al., 2003), food preference or feeding habits cannot be observed by these means (Erickson et al., 2003). Gut content can be influenced by the digestibility of food, and does not automatically reflect preference; it can also be linked to food availability (Erickson et al., 2003). Moreover, since there is a considerable range in the quantity of leaves and propagules over time and between different areas (Clarke, 1994), we could not measure preferences with gut content analysis because of this food availability difference. We therefore decided to use binary choice. The experiment was performed under
R. mucronata canopy with $N$. smithii and under A. marina canopy with $N$. africanum. Firstly, we observed the crab population for $15 \mathrm{~min}$ and noted in which direction the randomly chosen crabs entered burrows. Based on this observation, we placed two different food items in such a way that the crabs exiting their burrows discovered both items of food simultaneously. The food consisted of fresh leaves collected directly from the dominant cover species of the study site, and mature propagules of $A$. marina or C. tagal from the study site. We placed both items of food at an equal distance of $20 \mathrm{~cm}$ from the target burrow, and we noted which was depredated on first. The observer was at least five metres away from the burrows. In order to avoid being seen by the target crab, the observer stayed behind the crab and avoided making any movements. The experiment was repeated 20 times with 20 different crabs for each combination of food items. Cases where the food item was first taken by a non-target crab were excluded from analysis, in order to avoid the selection of the piece of food which was closer or which was seen first. We considered that propagules or leaves were chosen and depredated when they were inside burrows. We tested leaves against propagules (A. marina and C. tagal), and propagules against propagules. To test the confounding effect of propagule colour contrast on food choice (C. tagal is dark green, A. marina is light green and the soil is dark brown), we made a comparison between $C$. tagal (dark green) and A. marina (light green) with and without the periderm (dark green). It is not a rare occurrence to find A. marina propagules without their periderm; it is naturally lost after a few days (Rabinowitz, 1978). This took us approximately 9 days distributed throughout a 6 week period.

\subsection{Statistical analyses}

For all statistical analyses we used R software. A non-parametric Spearman correlation was used to test the statistical dependence between the number of depredated propagules and crab density. We used a binomial test to define whether predation was due to chance (approximately a $50 \%$ chance of obtaining the propagule), or whether one crab was a better competitor. A non-parametric Kruskal-Wallis rank sum test was used to test for significant differences in the speed of crab predation on both propagule species under different covers and different crab species pressure. A nonparametric pairwise Wilcoxon test was then conducted to determine the significance of predation speed differences between tree cover levels and between propagule species. To test for association between tree density and crab density, we used a Spearman correlation with $\log 10$ for pneumatophore density to reduce skewness of distributions. A binomial test was used to test the crabs' food electivity. This test compares the probability whether their food choices were due to chance (a $50 \%$ chance of choosing one of the two items) or whether there was an 'active' choice. We chose to use non-parametric tests when our data did not have a normal distribution and/or did not meet the homoscedasticity condition.

\section{Results}

\subsection{Impact of crab density on predation}

There was a high correlation between crab density and predation rate both under $R$. mucronata and $A$. marina canopies. We observed the same general trend in both cases (Fig. $1 \mathrm{a}-\mathrm{c}$ ). The number of propagules consumed tended to increase with crab density. There was a significant correlation between crab density and the predation rate of $A$. marina and $C$. tagal propagules under resp. R. mucronata and A. marina cover was evident. However, Fig. 1 

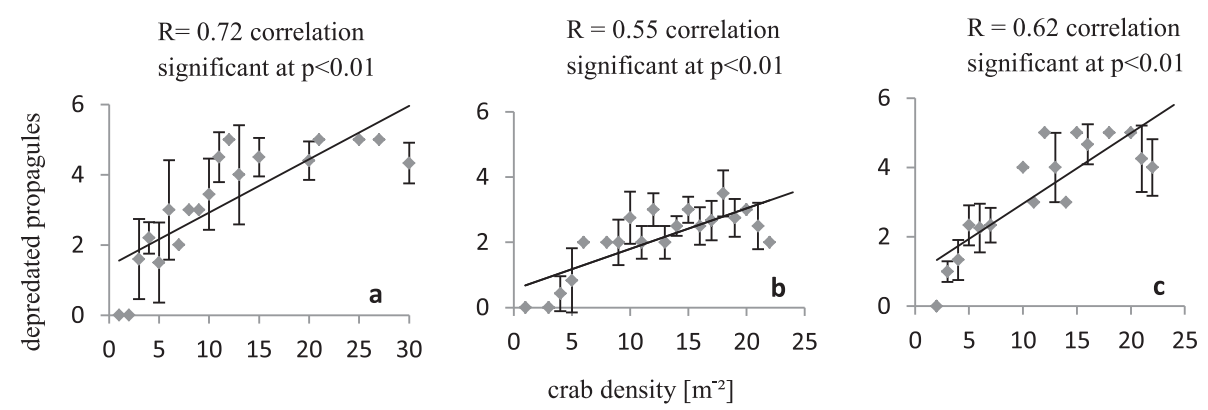

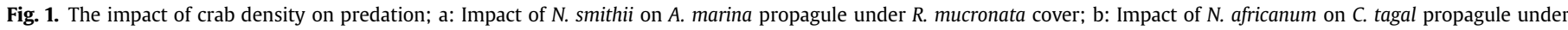
A. marina cover; c: Impact of $N$. africanum on A. marina propagule under A. marina cover.

also showed that propagule predation tends to decrease with crab densities higher than 20 individuals per $\mathrm{m}^{2}$.

\subsection{Importance of crab size in food competition}

There was a competitively dominant crab in eight out of the eleven pairs analysed (Table 2). However, competitive dominance was not related to size (large and small crabs "won" four times each). The average carapace widths for larger and smaller conspecific crabs were $3.4 \mathrm{~cm} \pm 0.3$ and $1.8 \mathrm{~cm} \pm 0.2$, respectively.

\subsection{Rates of crab predation on propagules}

We observed that $A$. marina propagules were consumed faster than $C$. tagal propagules (Table 3, Fig. 2a, b), and that this was independent of the species cover. We also observed that $A$. marina and $C$. tagal propagules were depredated faster under conspecific cover. There was a significant difference between $A$. marina propagule predation speed under $A$. marina cover and the other species cover types, and between $C$. tagal and $R$. mucronata cover (Table 3 ). A significant difference between $C$. tagal propagule predation speed under $C$. tagal cover and the other species covers was observed, but not between $A$. marina and $R$. mucronata covers. The crab densities under C. tagal, A. marina and $R$. mucronata were $10 \mathrm{~m}^{-2} \pm 0.5$, $12 \mathrm{~m}^{-2} \pm 1.5$ (N. africanum) and $10.5 \mathrm{~m}^{-2} \pm 0.7$ (N. smithii), respectively $(n=20)$.

\subsection{Relationship between vegetation density and crab density}

We found a significant negative correlation between tree density and crab density (Fig. 3a). We have also found a significant negative correlation between the density of $A$. marina pneumatophores and crab density (Fig. 3b). Sesarmid crabs were totally absent in the absence of mangrove trees.

\subsection{Food preference}

$N$. smithii individuals have no food preferences and interchangeably chose the two propagule species (A. marina and C. tagal) and $R$. mucronata leaves (Table 4), although they tended to choose A. marina propagules or $R$. mucronata leaves first. In contrast, $N$. africanum significantly selected leaves or propagules of $A$. marina over $C$. tagal propagules. We observed the same behaviour regardless if $A$. marina propagules have their periderm intact or not. However, there was no variation in the predator's feeding choice when we compared $A$. marina leaves and $A$. marina propagules. We have only observed a tendency to choose $A$. marina propagules.
Table 2

The importance of crab size in food competition using Binomial test. $N$ : number of replications; Obs. Prop.: observed proportions; *: significant at $p<0.05$.

\begin{tabular}{|c|c|c|c|c|}
\hline \multirow{2}{*}{$\begin{array}{l}\text { Pairs of crabs } \\
1^{*}\end{array}$} & \multirow{2}{*}{$\begin{array}{l}N \\
\\
16\end{array}$} & \multicolumn{2}{|c|}{$\begin{array}{l}\text { Obs. Prop. (Larger } \\
\text { carb versus smaller } \\
\text { crab) }\end{array}$} & \multirow[t]{2}{*}{$P$ value } \\
\hline & & 0.94 & 0.06 & \\
\hline 2 & 14 & 0.43 & 0.57 & 0.791 \\
\hline 3 & 15 & 0.67 & 0.33 & 0.302 \\
\hline $4^{*}$ & 16 & 0.19 & 0.81 & 0.021 \\
\hline $5^{*}$ & 16 & 1.00 & 0.00 & $<0.0001$ \\
\hline $6^{*}$ & 16 & 0.06 & 0.94 & 0.001 \\
\hline 7 & 16 & 0.69 & 0.31 & 0.210 \\
\hline $8^{*}$ & 16 & 1.00 & 0.00 & $<0.0001$ \\
\hline $9^{*}$ & 16 & 0.12 & 0.88 & 0.004 \\
\hline $10^{*}$ & 16 & 0.06 & 0.94 & 0.001 \\
\hline $11^{*}$ & 16 & 0.88 & 0.12 & 0.004 \\
\hline
\end{tabular}

Table 3

Rate of crab predation on propagules, cover effect and species effect on A. marina and C. tagal propagule using Wilcoxon test.*: significant at $p<0.05$.

\begin{tabular}{lr}
\hline & $P$ value \\
\hline Rate of crab predation on A. marina propagule & \\
A. marina versus C. tagal covers* & 0.028 \\
R. mucronata versus C. tagal covers* & $<0.001$ \\
A. marina versus . mucronata covers* & $<0.001$ \\
Rate of crab predation on C. tagal propagule & \\
A. marina versus C. tagal covers* & $<0.001$ \\
R. mucronata versus C. tagal covers* & $<0.001$ \\
A. marina versus $R$. mucronata covers & 0.61 \\
Rates of crab predation on C. tagal versus A. marina propagule & \\
& $<0.001$ \\
\hline
\end{tabular}

\section{Discussion}

\subsection{Impact of crab density on predation}

As expected, we found propagule predation to be strongly, and positively correlated with crab density. It is already known that leaf consumption increases at high crab densities (Beever et al., 1979). Based on our results, it seems to be difficult for a propagule to germinate and hence a plant to establish at high crab densities.

Propagule predation increased with crab density, but under higher crab densities the quantity of depredated propagules decreased slightly. This could be because of a difference in energy allocation. Crabs have to manage higher competition for territory due to the larger number of conspecifics, and therefore allocate more time and energy to territory defense than to feeding activity. This density threshold implies that above this limit, a higher density of N. smithii and N. africanum has less impact on predation than at lower density. Crab density could be a proxy of predation rate but 

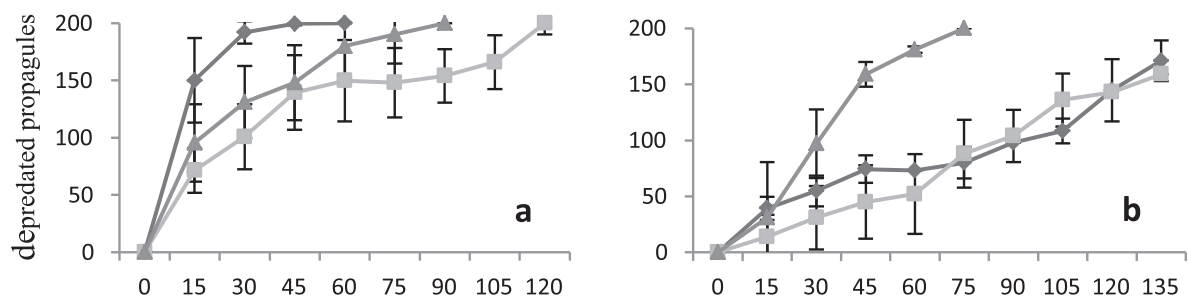

time $[\mathrm{min}]$

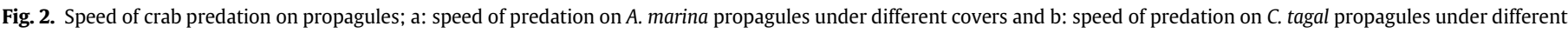
covers: $\diamond=$ A. marina cover (predation by $N$. africanum); $\square=R$. mucronata cover (predation by $N$. smithii); $\Delta=C$. tagal cover (predation by $N$. africanum).

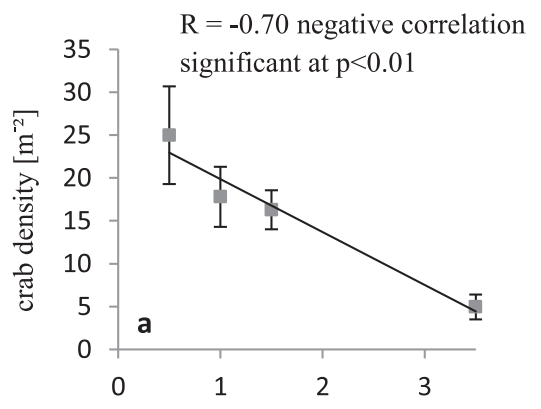

A. marina tree density $\left[\mathrm{m}^{-2}\right]$

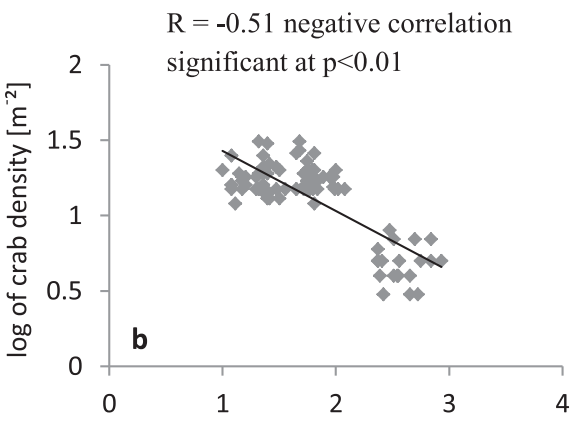

$\log$ of A. marina pneumatophore density $\left[\mathrm{m}^{-2}\right]$

Fig. 3. Relationships between vegetation density and crab density; a: Tree density vs. N. africanum density; b: Pneumatophore density vs. N. africanum density.

their relationship would not be linear. It would be interesting to repeat this experiment covering sites with higher crab density.

\subsection{Importance of crab size in food competition}

The reported dependence of crab competition related to their respective sizes (Piou et al., 2007) is adapted from the Field of Neighbourhood approach (FON) that was originally developed to consider neighbouring competition for sessile organisms such as trees in individual-based models (Berger and Hildenbrandt, 2000; Berger et al., 2004). It is already known that size is correlated with the quantity of leaves ingested (Emmerson and McGwynne, 1992; Nordhaus et al., 2006). Moreover, the results of Fratini et al. (2011) indicate that the ability to capture leaves depends, firstly, on the distance between crabs and leaves, with the closest crabs obtaining the leaves; and secondly, on crab size, with the larger crab obtaining the leaves (Fratini et al., 2011). However, our results show that crab size does not influence their intraspecies competitive dominance.

In this experiment no real contact between crabs was recorded. The crab that obtained the propagule was the first to reach the item, not the one that pull it the strongest. This is likely due to the types of food we tested: A. marina propagules are small, easily buried and seem to reduce crab confrontation. Therefore, crabs had no opportunity to fight for food. It is possible that a test with bigger propagules, such as those of $C$. tagal or $R$. mucronata, would provide contrasting results (see Cannicci et al., 2008). As we observed in the field, crabs may fight more frequently for bigger propagules though this remains to be statistically tested.

Earlier studies relying on burrow entry size as a proxy for predatory behaviour of crabs (Dahdouh-Guebas et al., 2011) were found to be not true for all crab species. Our results imply that when investigating herbivory or propagule predation in an ecological functioning context, both large and small crabs should be taken into account. This study shows that small crabs and larger crabs may have a similar impact on predation and mangrove regeneration. We must be cautious with these results because only 11 pairs of crabs were tested. More replicas and more sites would need to be tested in order to confirm this tendency and to generalize these findings.

\subsection{Rates of crab predation on propagules}

We observed that $A$. marina propagules were depredated slightly faster than $C$. tagal propagules. Two hundred $A$. marina propagules were depredated in $79 \mathrm{~min}$ on average $( \pm 7 \mathrm{~min}$ ) while 200 C. tagal were depredated in $150 \mathrm{~min}$ on average $( \pm 12 \mathrm{~min})$. These results corroborate the hypothesis of preference for an Avicennia spp. propagules (see Smith, 1987; McKee, 1995). These results also show the difficulty for a propagule to survive and germinate. One possible strategy for trees could be to produce so many propagules that predators, such as crabs, reach a saturation point in their feeding (Dahdouh-Guebas et al., 1997). Preliminary results indicate an average of $257 \pm 70 \mathrm{C}$. tagal propagules and $294 \pm 64$ A. marina propagules per tree $(n=12)$ (but they were not equally mature; personal observations). This does not seem enough to counteract the predation pressure on propagules, as 200 propagules can be rapidly depredated according to our observations. An alternative strategy for propagules could be to establish in an area where predation pressure is low or absent. Indeed, A. marina propagules are more mobile through the root network than bigger propagules (personal communication De Ryck) and thus have the possibility of colonizing free space where there is less competition and less predation. To maximize that strategy, trees would need to synchronize propagule abscission with the tidal flooding. Indeed, preliminary results, from the same study site, show that an average of $6 \pm 2$ A. marina propagules per tree fell during high tide and no propagules fell during low tide. Five trees were observed during four high and four low tides. More experiments have to be 
Table 4

Feeding preference and food electivity using Binomial test. Lvs: leaves; Prop: propagules; Lgr: light green (A. marina propagules with envelope); Dgr: Dark green (A. marina propagules without envelope); $\mathrm{N}$ : number of replications; Obs. \%.: observed percentage; *: significant at $p<0.05$.

\begin{tabular}{lccc}
\hline Food items & $N$ & Obs. $\%$ & $P$ value \\
\hline N. smithii food electivity under $\boldsymbol{R}$. mucronata cover & & \\
Lvs of $R$. mucronata versus C. tagal Prop. & 22 & $73 \% / 27 \%$ & 0.052 \\
C. tagal Prop versus A. marina Prop & 25 & $31 \% / 69 \%$ & 0.210 \\
A. marina Prop versus Lvs of . mucronata & 24 & $71 \% / 29 \%$ & 0.064 \\
N. africanum food electivity under $\boldsymbol{A}$. marina cover & & \\
A. marina Prop Lgr versus C. tagal Prop* & 22 & $91 \% / 09 \%$ & $<0.0001$ \\
A. marina Prop Dgr versus C. tagal Prop* & 20 & $100 \% / 0 \%$ & $<0.0001$ \\
A. marina Prop versus Lvs of A. marina & 22 & $68 \% / 32 \%$ & 0.134 \\
Lvs of A. marina versus C. tagal Prop* & 22 & $86 \% / 14 \%$ & 0.001 \\
\hline
\end{tabular}

conducted in order to unravel whether that phenomenon is consistent over time, across sites and mangrove species.

\subsection{Relationship between vegetation density and crab density}

Crab distribution within the study site was heterogeneous. Contrary to our hypothesis, crab density seems to be inversely related to tree density. We also observed a negative correlation between pneumatophore quantity and crab density.

High pneumatophore density may limit burrow construction, crab movement, and food harvesting, particularly in the case of large crabs. This suggests a non-trophic bottom-up control of the vegetation on the primary consumer. It is possible that there is above- and below-ground competition for space between roots and crabs. Alternatively, pneumatophore density affect soil properties (McKee et al., 1988) and thus the presence of crab burrows.

Similarly, we noted that no sesarmid crabs were found in adjacent gap areas. Several assumptions can be put forward in order to explain these results: heating due to solar radiation, desiccation (Fusi et al., unpublished results) and vulnerability to predators (birds). Indeed, sesarmids are more sensitive to heat and desiccation than some other crab families (Fusi et al., unpublished results). In addition to these observations, it is more than likely that these herbivorous crabs do not affect the regeneration and spontaneous colonization of mangroves on bare soils. This hypothesis is supported by the results of Farnsworth and Ellison (1991), who found that Rhizophora mangle seedlings under an adult canopy suffered from a level of predation twice as high as seedlings growing in areas without adult canopy. Osborne and Smith (1990) also found that predation rate was higher under a closed canopy than in gap areas. These results follow the canopy-gap mediated model, which stipulates that predation can be more intense under the canopy than in large gaps (Osborne and Smith, 1990; Clarke and Kerrigan, 2002), where higher temperature (Fusi et al., unpublished results), and lack of food (Bosire et al., 2005) discourages sesarmid crab establishment.

A relationship between the number of canopy strata and the density of crabs has been observed in the field, but not quantified yet. We have seen that under very dense cover a large number of juvenile and young plants are present. This dense vegetation can also affect crab density through competition for space. But the opposite is also true: the presence of fewer crabs can lead to reduced predation and increased survival of seedlings. It is also true that under low densities of larger trees there are fewer juvenile or young plants which provide less competition for space and this can affect crab density. Conversely, more crabs may lead to more predation and to fewer plant juveniles. The 'mutual relationship' between sesarmid crabs and mangroves, as crabs reduce competition between seedlings through propagule predation and mangroves provide food and protection for crabs (Bosire et al., 2005; Cannicci et al., 2008), should be more pronounced in areas with a reduced canopy cover and with fewer pneumatophores. It would be useful to expand these experiments to other sites and to compare crab density and size with vegetation structure.

\subsection{Food preference}

Crabs of the Sesarmidae family are almost all herbivores but are not strictly propagule eaters. Indeed, these crabs also feed on all fallen litter on the ground. Leaves are, despite their low nutritional value, the main source of nutrients for these crabs (Slim et al., 1997; Skov and Hartnoll, 2002; Schories et al., 2003). In fact, according to Dahdouh-Guebas et al. (1999), the predominant component of the stomach content of these crabs is leaves (up to 90\%). These crabs predominantly consume leaves and algae and may, in some cases, be carnivorous (Dahdouh-Guebas et al., 1999). This can be due to the variation in relative abundance of leaves on the forest floor compared to propagules (Clarke, 1994). Mangrove trees follow a circannual cycle and do not fructify throughout the year, but during specific periods (Tomlinson, 1986). However some authors have demonstrated that crab predation on propagules affects recruitment, regeneration and mangrove vegetation structure through propagule selection (Smith, 1987; Smith et al., 1989; Osborne and Smith, 1990; Weinstock, 1994; McKee, 1995; McGuinness, 1997; Lindquist and Carrol, 2004).

When $N$. smithii and $N$. africanum could choose between A. marina propagules and leaves, they were found to consume the two items interchangeably with a slight preference for A. marina propagules. This is contrary to the study of Salgado Kent and McGuinness (2008) where the preference was always for leaves. Our result does not correspond with the food preference experiment of Dahdouh-Guebas et al. (1997); but is in agreement with the hypothesis that crabs selectively choose and eat plants with a higher nutritional value (Smith, 1987; Farnsworth and Ellison, 1991; McKee, 1995; Clarke and Kerrigan, 2002; Ditzel Faraco and da Cunha Lana, 2004; Nordhaus et al., 2011). Indeed, A. marina leaves and propagules have a lower $\mathrm{C}: \mathrm{N}$ ratio and tannin content than C. tagal propagules (Smith, 1987; Rao et al., 1994; McKee, 1995; Wafar et al., 1997; Clarke and Kerrigan, 2002), and hence are of higher nutritional quality. According to the study of Erickson et al. (2004), vegetation chemistry does not completely explain the food preferences of crabs. Following the results of Micheli (1993) on feeding ecology and those of Feller (1995) on nutrient enrichment, herbivory is not affected by C: $\mathrm{N}$ ratio differences. Predation pressure, reproductive seasons, inter- and intra-specific competition (Erickson et al., 2004) and population dynamics (Ditzel Faraco and da Cunha Lana, 2004) could also be affecting the feeding habits of crabs.

The size of the food items may also be relevant. An initial expectation would be that crabs take the larger food item to obtain more nutrients, but in our study crabs always chose the smaller item, whether the leaves or A. marina propagules. We observed that crabs had more difficulty in transporting the larger $C$. tagal propagules quickly into their burrow. Other crabs which had the opportunity to compete for it pulled the opposite extremity of the propagule. Considering this observation, perhaps it is more rewarding to take the smaller item to avoid intra-specific competition and to increase the chance of keeping the food item. A previous study describes no significant effect of propagule size on preferences (Salgado Kent, 2004 in Salgado Kent and McGuinness, 2008), but some authors (Camilleri, 1989; McKee, 1995; Clarke and Kerrigan, 2002; Salgado Kent and McGuinness, 2008), based on analysis of feeding preferences with balanced sample sizes, suggest that the size of food items may be important. It is possible that 
crabs of different sizes depredate on food items of different dimensions.

If crabs visually recognize food, shape and size may be a cue; but also colour. We found that crabs selected dark green $A$. marina (without a seed coat) and light green $A$. marina (with a seed coat) propagules first, and equally, before $C$. tagal propagules. Therefore, there was no effect of colour within this range on propagule selection. Nonetheless, more experimental sites would need to be studied in order to generalize these findings.

\section{Conclusion}

We conclude that there is a mutual relationship between mangrove stand characteristics, crab densities and propagule predation rates.

Clearly, crab density has an impact on propagule predation rate. It could be useful to quantify this relationship in order to obtain direct information on recruitment rate and viability of a propagule cohort. A comparison of crab density and seedling establishment rate can offer a clearer idea of that relationship. Moreover, time and energy allocation to predation seems to decrease with high crab density. This may indicate a density dependent threshold. The consequences of such threshold-type relations in regulating mangrove structure and vegetation regeneration could be crucial.

Since crab size does not affect crab competition for food when they can directly bury the food item, there is an equal chance for large and small crabs to depredate when the food items are small, such as leaves and $A$. marina propagules. Small and large crabs would thus have the same impact on the regeneration of species that have small propagules.

The rate of crab predation on propagules was very high and it seems very difficult in such conditions for propagules to germinate and establish. Crab density could therefore be a good indicator for seedling establishment management.

Crabs are less numerous in areas with a high pneumatophore density. This could be related to competition for space. This hypothesis implies a non-trophic bottom-up control of the vegetation on primary consumers, and could be essential for plantation management. It may also be a driver of successional stages, if recruitment of a same species under its respective canopy is impeded after crab colonization.

It appears that crabs select food with high nutrient quality and food which can be easily dragged below-ground. A trade-off between energy allocation for predation, for competition, and energy from the food item, is possible and this could be affecting the selectivity of food items. Further studies would elucidate which of these electivity drivers is the most influential. This selectivity affects vegetation regeneration and structure.

Therefore, the management of natural and reforested mangrove forests depends on our understanding of the impact of crab predation on the germination of propagules, and the factors that influence crab predation rates. The mutual relationships between vegetation structure and crab density seem to influence propagule survival and seedling recruitment. Consequently these relationships should be taken into account for forest restoration and management.

\section{Acknowledgements}

We wish to thank the Kenyan Marine and Fisheries Research Institute (KMFRI) for technical and administrative support. We also wish to thank Hassan for fieldwork assistance and Latifa and her family for excellent accommodation in Gazi. We are also grateful to Jenny Booth and to Aina Astudillo Fernandez for language corrections. This project was partly financed by the 'Mandat d'Impulsion
Scientifique' (MIS ID 1765914) of the National Science Foundation (FNRS), Belgium. We are also really grateful for the valuable comments and remarks of the reviewers which greatly improved our paper.

\section{References}

Amarasinghe, M.D., Dulyapurk, V., Taparhudee, W., 2009. Mangroves of Nakhon Si Thammarat Province in southern Thailand: species diversity, community structure and current status. Aquac. Asia 14 (2), 20-22.

Beever III, J.W., Simberloff, D., King, L.L., 1979. Herbivory and predation by the mangrove tree crab Aratus Pisonii. Oecologia 43, 317-328.

Berger, U., Hildenbrandt, H., 2000. A new approach to spatially explicit modelling of forest dynamics: spacing, ageing and neighbourhood competition of mangrove trees. Ecol. Model. 132, 287-302.

Berger, U., Hildenbrandt, H., Grimm, V., 2004. Age-related decline in forest production: modelling the effects of growth limitation, neighbourhood competition and self-thinning. J. Ecol. 92, 846-853.

Bosire, J.O., Kazungu, J., Koedam, N., Dahdouh-Guebas, F., 2005. Predation on propagules regulates regeneration in a high-density reforested mangrove plantation. Mar. Ecol. Prog. Ser. 299, 149-155.

Bouillon, S., Koedam, N., Raman, A.V., Dehairs, F., 2002a. Primary producers sustaining macro-invertebrate communities in intertidal mangrove forests. Oecologia 130, 441-448.

Bouillon, S., Raman, A.V., Dauby, P., Dehairs, F., 2002b. Carbon and nitrogen stable isotope ratios of subtidal benthic invertebrates in an estuarine mangrove ecosystem (Andhra Pradesh, India). Estuar. Coast. Shelf Sci. 54, 901-913.

Camilleri, J., 1989. Leaf choice by crustaceans in a mangrove forest in Queensland. Mar. Biol. 102, 453-459.

Cannicci, S., Ritossa, S., Ruwa, R.K., Vannini, M., 1996. Tree fidelity and hole fidelity in the tree crab Sesarma leptosome (Decapoda, Grapsidae). J. Exp. Mar. Biol. Ecol. 196, 299-311.

Cannicci, S., Gomei, M., Dahdouh-Guebas, F., Rorandelli, R., Terlizzi, A., 2007. Influence of seasonal abundance and food quality on the feeding habits of an opportunistic feeder, the intertidal crab Pachygrapsus marmoratus. Mar. Biol. 151, 1331-1342.

Cannicci, S., Burrows, D., Fratini, S., Lee, S.Y., Smith III, T.J., Offenberg, J., DahdouhGuebas, F., 2008. Faunistic impact on vegetation structure and ecosystem function in mangrove forests: a review. Aquat. Bot. 89 (2), 186-200.

Cannicci, S., Bartolini, F., Dahdouh-Guebas, F., Fratini, S., Litulo, C., Macia, A., Mrabu, E.J., Penha-Lopes, G., Paula, J., 2009. Effects of urban wastewater on crab and mollusk assemblages in equatorial and subtropical mangroves of East Africa. Estuar. Coast. Shelf Sci. 84, 305-317.

Clarke, P.J., 1994. Baseline studies of temperate mangrove growth and reproduction; demographic and litterfall measures of leafing and flowering. Aust. J. Bot. 42, 37-48.

Clarke, P.J., Kerrigan, R.A., 2002. The effects of seed predators on the recruitment of mangroves. J. Ecol. 90, 728-736.

Dahdouh-Guebas, F., Verneirt, M., Tack, J.F., Koedam, N., 1997. Food preferences of Neosarmatium meinerti de man (Decapoda: Sesarminae) and its possible effect on regeneration of mangroves. Hydrobiologia 347, 83-89.

Dahdouh-Guebas, F., Verneirt, M., Tack, J.F., Van Speybroeck, D., Koedam, N., 1998 Propagule predators in Kenya mangroves and their possible effect on regeneration. Mar. Freshw. Res. 49, 345-350.

Dahdouh-Guebas, F., Giuggioli, M., Oluoch, A., Vannini, M., Cannicci, S., 1999. Feeding habits of non-ocypodid mangrove crabs from Kenya. Bull. Mar. Sci. 64 (2), 291-297.

Dahdouh-Guebas, F., Vermeirt, M., Cannicci, S., Kairo, J.G., Tack, J.F., Koedam, N., 2002. An exploratory study on grapsid crab zonation in Kenyan mangroves. Wetl. Ecol. Manag. 10, 179-187.

Dahdouh-Guebas, F., De Bondt, R., Abeysinghe, P.D., Kairo, J.G., Cannicci, S., Triest, L., Koedam, N., 2004. Comparative study of the disjunct zonation pattern of the grey mangrove Avicennia marina (Forsk.) Vierh. in Gazi Bay (Kenya). Bull. Mar. Sci. 74 (2), 237-252.

Dahdouh-Guebas, F., Kairo, J.G., De Bondt, R., Koedam, N., 2007. Pneumatophore height and density in relation to micro-topography in the grey mangrove Avicennia marina. Belg. J. Bot. 140 (2), 213-221.

Dahdouh-Guebas, F., Koedam, N., Satyanarayana, B., Cannicci, S., 2011. Human hydrographical changes interact with propagule predation behaviour in Sri Lankan mangrove forest. J. Exp. Mar. Biol. Ecol. 399 (2), 188-200.

Ditzel Faraco, L.F., da Cunha Lana, P., 2004. Leaf-consumption levels in subtropical mangroves of Paranaguá Bay (SE Brazil). Wetl. Ecol. Manag. 12 (2), 115-122.

Emmerson, W.D., McGwynne, L.E., 1992. Feeding and assimilation of mangrove leaves by the crab Sesarma meinerti de man in relation to leaf-litter production in Mgazana, a warm-temperate southern African mangrove swamp. J. Exp. Mar. Biol. Ecol. 157, 41-53.

Erickson, A.A., Saltis, M., Bell, S.S., Dawes, C.J., 2003. Herbivore feeding preferences as measured by leaf damage and stomatal ingestion: a mangrove crab example. J. Exp. Mar. Biol. Ecol. 289, 123-138.

Erickson, A.A., Bell, S.S., Dawes, C.J., 2004. Does mangrove leaf chemistry help explain crab herbivory patterns? Biotropica 36 (3), 333-343.

Farnsworth, E.J., Ellison, A.M., 1991. Patterns of herbivory in Belizean mangrove swamps. Biotropica 23 (4b), 555-567. 
Farnsworth, E.J., Ellison, A.M., 1997. Global patterns of pre-dispersal propagule predation in mangrove forests. Biotropica 29 (3), 318-330.

Feller, I.C., 1995. Effect of nutrient enrichment on growth and herbivory of dwarf red mangrove (Rhizophora mangle). Ecol. Monogr. 65, 477-505.

Fratini, S., Sacchi, A., Vannini, M., 2011. Competition for mangrove leaf litter between two East African crabs, Neosarmatium meinerti (Sesarmidae) and Cardisoma carnifex (Gecarcinidae): a case of kleptoparasitism? J. Ethol. 29, $481-485$.

Krauss, K.W., Lovelock, C.E., McKee, K.L., Lopez-Hoffman, L., Ewe, S.M., Sousa, W.P. 2008. Environmental drivers in mangrove establishment and early development: a review. Aquat. Bot. 89 (2), 105-127.

Kristensen, E., 2007. Mangrove crabs as ecosystem engineers; with emphasis on sediment processes. J. Sea Res. 59, 30-43.

Lee, S.Y., 1999. Tropical mangrove ecology: physical and biotic factors influencing ecosystem structure and function. Aust. J. Ecol. 24, 355-366.

Lindquist, E.S., Carrol, C.R., 2004. Differential seed and seedling predation by crabs: impacts on tropical coastal forest composition. Oecologia 141, 661-671.

Lindquist, E.S., Krauss, K.W., Green, P.T., O'Dowd, D.J., Sherman, P.M., Smith III, T.J., 2009. Land crabs as key drivers in tropical coastal forest recruitment. Biol. Rev. 84, 203-223.

Macnae, W., 1968. A general account of the fauna and flora of mangrove swamps and forests in the Indo-West-Pacific region. Adv. Mar. Biol. 6, 73-270.

Matthijs, S., Tack, J., van Speybroeck, D., Koedam, N., 1999. Mangrove species zonation and soil redox state, sulphide concentration and salinity in Gazi Bay (Kenya) a preliminary study. Mangroves Salt Marshes 3, 243-249.

McGuinness, K.A., 1997. Seed predation in a tropical mangrove forest: a test of the dominance-predation model in northern Australia. J. Trop. Ecol. 13, 293-302.

McKee, K.L., Mendelssohn, I.A., Hester, M.W., 1988. Reexamination of pore water sulfide concentrations and redox potentials near the aerial roots of Rhizophora mangle and Avicenia germinans. Am. J. Bot. 75 (9), 1352-1359.

McKee, K.L., 1995. Mangrove species distribution and propagule predation in Belize: an exception to the dominance-predation hypothesis. Biotropica 27 (3), $334-345$.

Micheli, F., Gherardi, F., Vannini, M., 1991. Feeding and burrowing ecology of two East African mangrove crabs. Mar. Biol. 111, 247-254.

Micheli, F., 1993. Feeding ecology of mangrove crabs in North Eastern Australia: mangrove litter consumption by Sesarma messa and Sesarma smithii. J. Exp. Mar. Ecol. 171, 165-186.

Neukeurmans, G., Dahdouh-Guebas, F., Kairo, J.G., Koedam, N., 2008. Mangrove species and stand mapping in Gazi bay (Kenya) using quickbird satellite imagery. J. Spat. Sci. 53, 75-86.

Nicholson, C., 2009. Mangroves and Crabs as Ecosystem Engineers in Zanzibar. Independent Study Project (ISP) Collection. Paper 760.

Nordhaus, I., Wolff, M., Diele, K., 2006. Litter processing and population food intake of the mangrove crab Ucides cordatus in a high intertidal forest in northern Brazil. Estuar. Coast. Shelf Sci. 67, 239-250.
Nordhaus, I., Salewski, T., Jennerjahn, T., 2011. Food preferences of mangrove crabs related to leaf nitrogen compounds in the Segara Anakan Lagoon, Java, Indonesia. J. Sea Res. 65, 414-426.

Osborne, K., Smith, T.J., 1990. Differential predation on mangrove propagules in open and closed canopy forests habitats. Vegetation 89, 1-6.

Piou, C., Berger, U., Hildenbrandt, H., Grimm, V., Diele, K., D'Lima, C., 2007. Simulating cryptic movements of a mangrove crab: recovery phenomena after small scale fishery. Ecol. Model. 205, 110-122.

Rabinowitz, D., 1978. Dispersal properties of mangrove propagules. Biotropica 10 47-57.

Rao, R.G., Woitchik, A.F., Goeyens, L., van Riet, A., Kazungu, J., Dehairs, F., 1994 Carbon, nitrogen contents and stable carbon isotope abundance in mangrove leaves from an east African lagoon (Kenya). Aquat. Bot. 47, 175-183.

Robertson, A.I., Giddins, R., Smith, T.J., 1990. Seed predation by insects in tropical mangrove forests: extent and effects on seed viability and the growth of seedlings. Oecologia 83, 213-219.

Salgado Kent, C.P., 2004. The Significance of Plant-animal Interactions: How Crabs Affect Structure and Function (Phd thesis). Charles Darwin University, Australia.

Salgado Kent, C.P., McGuinness, K.A., 2008. Feeding Selectivity of Sesarmid Crabs from Northern Australian Mangrove Forests. In: Records of the Museums and Art Galleries of the Northern Territory, vol. 24. Beagle, pp. 23-32.

Schories, D., Barletta-Bergan, A., Barletta, M., Krumme, U., Mehlig, U., Rademaker, V., 2003. The keystone role of leaf-removing crabs in mangrove forests of North Brazil. Wetl. Ecol. Manag. 11, 243-255.

Skov, M., Hartnoll, R.G., 2002. Paradoxal selective feeding on a low-nutrient diet why do mangrove crabs eat leaves? Oecologia 131, $1-7$.

Slim, F.J., Hemminga, M.A., Ochieng, C., Jannink, N.T., Cocheret de la Morinière, E. van der Velde, G., 1997. Leaf litter removal by the snail Terebralia palustris (Linnaeus) and sesarmid crabs in an East African mangrove forest (Gazi Bay Kenya). J. Exp. Mar. Biol. Ecol. 215, 35-48.

Smith III, T.J., 1987. Seed predation in relation to tree dominance and distribution in mangrove forests. Ecology 68 (2), 266-273.

Smith III, T.J., Chan, H.T., McIvor, C.C., Robblee, M.B., 1989. Comparisons of seed predation in tropical, tidal forests from three continents. Fcology 70, 146-151.

Thongtham, N., Kristensen, E., 2005. Carbon and nitrogen balance of leaf-eating sesarmid crabs (Neoepisesarma versicolor) offered different food sources. Estuar. Coast. Shelf Sci. 65, 213-222.

Tomlinson, P.B., 1986. The Botany of Mangroves. Cambridge University Press, Cambridge.

Tomlinson, P.B., Cox, P.A., 2000. Systematic and functional anatomy of seedlings in mangrove Rhizophoraceae: vivipary explained? Bot. J. Linn. Soc. 134, 215-231.

Wafar, S., Untawale, A.G., Wafar, M., 1997. Litter fall and energy flux in a mangrove ecosystem. Estuar. Coast. Shelf Sci. 44, 111-124.

Weinstock, J.A., 1994. Rhizophora mangrove agroforestry. Econ. Bot. 48 (2), 210-213.

Wilson, K.A., 1989. Ecology of mangrove crabs: predation, physical factors and refuges. Bull. Mar. Sci. 44 (1), 263-273. 